\title{
S5ynthesis
}

International Scientific Conference of IT and Business-Related Research

\section{SPECIJALISTIČKA PODRUČJA MENADŽMENTA U SPORTU}

\author{
SPECIALIST AREAS OF SPORT MANAGEMENT
}

\author{
Sretenka Dugalić, Snežana Lazarević \\ Univerzitet Singidunum, Fakultet za fizičku kulturu i menadžment u sportu, Danijelova 32, Beograd, Srbija
}

\begin{abstract}
Apstrakt:
Sportsku industriju karakterišu visoka stopa rasta, obim prihoda, i globalizacija. To zahteva teorijsko redefinisanje sportskog biznisa, koji se u Srbiji zbog sporijeg rasta i manjeg značaja u strukturi DPB (društvenog bruto proizvoda) klasifikuje kao sportska delatnost. Sport zbog visoke konkurentnosti podstiče globalizacija, organizuje se na profesionalni način, stvara se institucionalni okvir za sportski biznis, teorijski objašnjava restrukturiranje sporta u svetlu turbulentne savremene sportske prakse, i edukuje posebna struka menadžera u sportu na svim nivoima studija.

U radu su elaborirani brojni faktori koji podstiču ekspanziju sportskog biznisa. Zahvaljujući toj kauzalnoj vezi, na temeljima ekonomije i menadžmenta, u teoriji sporta su se razvila specijalistička područja: menadžment sportskih objekata, menadžment sportskih takmičenja, i sl., sa tendencijom širenja disciplinarnih područja. U Srbiji je menadžment u sportu svrstan u društveno-humanističko polje, oblast menadžment i biznis, uža oblast menadžment u sportu. Sportski menadžment već više decenija opravdava svrhu svog postojanja prateći naučne, privredne, strukovne, i edukativne trendove koji postoje u svetu, čime doprinosi razvoju sporta i sportskog biznisa.
\end{abstract}

\section{Ključne reči:}

teorija sporta, ekonomija, menadžment, discipline sportskog menadžmenta.

\section{UVOD}

Sport je nastao sa pojavom ljudske civilizacije. Istorija sporta objašnjava njegove uzročno-posledične veze sa ostalim aspektima ljudskog stvaralaštva u različitim, sukcesivnim slojevima društva, i uvodi nas u posebno značajan period razvoja sporta, vreme antičke Grčke i ustanovljavanje Olimpijskih igara (OI) 776. godine p.n.e. Postoji dokumentaciona osnova iz tog perioda koja svedoči o pratećim, logističkim aktivnostima sporta: organizovanje sportskih takmičenja, sponzorisanje učesnika i velikih sportskih događaja. Pokret je krajem XIX veka doživeo renesansu. Zaključno sa OI u Londonu 2012 godine, broj zemalja učesnica iznosio je 204 (od 193 zemlje članice UN, a Olimpijski komitet do 2014. godine obrazovan je u 205 zemalja). Na zadnjim letnjim OI 10.500 učesnika se takmičilo u 36 sportova, i 302 discipline. Ovako značajan rast interesovanja savremenog društva za sport prate privredne aktivnosti kao logistička podrška sportu. Funkcije sportskog menadžmenta, i njegova specijalistička područja nastale pre 28 vekova, dopunjene su ustanovljavanjem modernih OI 1894. godine, pojavom korporativnog sponzorstva (kompanije Spirs i Paund 1861. go-

\section{Abstract:}

Sports industry is characterized by high growth rate, volume of income, and globalization. This requires theoretical redefining of sports business, which is classified as a sports activity in Serbia, due to slower growth and decline in the importance in the structure of GDP (gross domestic product). Due to high competition and globalization, sport is organized in a professional manner, thus creating the institutional framework for sports business. It theoretically explains the restructuring of sport in the light of the turbulent modern sports practice, and educates the special type of sports managers at all levels of study.

The paper elaborates on a number of factors triggering expansion of sports business. Owing to such causal relationship and based on the fundamentals of economics and management, the following specialist areas have emerged within the theory of sport: management of sports facilities, management of sports competitions, etc., with a tendency to expand disciplinary fields. Sports management in Serbia belongs to the area of social sciences and humanities, management and business, the narrow field of sports management. Sports management has attempted to justify the purpose of its existence for decades, by keeping pace with the scientific, economic, professional, and educational trends worldwide, thus contributing to the development of sport and sports business.

\section{Key words:}

theory of sport, economics, management, sports management discipline.

dine sponzorisale su turnir kriketa u Australiji), i naglim rastom broja kompanija koje participiraju u sponzorstvu od 1980. god. do danas. Uz brojne faktore koji su uticali na nastanak i razvoj današnje sportske industrije, sportski menadžment je doprineo burnom razvoju sporta, kao posebne profesije koja rastom kompetencija može odgovoriti zahtevima svog vremena.

Cilj rada je istražiti uzročno-posledičnu vezu istorije sporta i za nju vezanih privrednih aktivnosti: oživljavanje olimpijskog pokreta; industrijalizaciju; globalizaciju; razvoj tržišta, konkurenciju, itd. Na osnovu navedenog, primenom naučnih metoda, u radu ćemo (istorijska, komparativna, metoda eksplikacije) objasniti potrebu odvajanja menadžmenta u sportu (i njegovih disciplinarnih područja) kao posebne naučne oblasti koja egzistira u sportskoj teoriji i praksi.

\section{NASTANAK SPORTSKOG MENADŽMENTA}

Prema Kastratović (2004, str. 58), u poslednjih nekoliko stotina godina svi elementi koji čine strukturu menadžmenta $\mathrm{u}$ sportu, primerenu datom istorijskom trenutku, obezbeđuju i omogućavaju organizovanje sportskih događaja na način koji 
zadovoljava potrebe i želje učesnika - takmičara, sponzora i gledalaca. Prema Hardijevom modelu rasta sportskog tržišta (Pitts \& Stotlar, 1996), sportska industrija prolazi kroz etape razvoja: period buđenja (1800-1860), period tržišne svesti (1860-1880), i period konkurencije (1880-1990). Model privrednih era pojavu marketinga datira od 1950. godine i dalje. Fulertonov model prikazuje razvoj marketinga u fazama: period nastanka (18301870), institucionalnog razvoja (1870-1930), ustanovljenja i usavršavanja (1930-1980). Pitts i Stotlar razvoj sportskog marketinga tumače u sličnim fazama.

Fizičko vaspitanje u školama u Srbiji primenjuje se od 1808. godine, prvo u okviru predvojničke obuke; u javne škole fizičko vaspitanje uvedeno je 1844. god, a prve privatne škole (mačevanja, plivanja, borenja i gimnastike) nastaju od 1857. godine (Prvo srpsko društvo za gimnastiku i borenje), kao preteče današnjih sportskih klubova. Od druge polovine XIX veka na našim prostorima se javila potreba za logističkom podrškom sportu, putem nekih od poslovnih funkcija (organizovanje, vođenje, finansiranje). Prvu polovinu XX veka karakterišu česti ratovi i izmene društveno-ekonomskog sistema, pa se etape u razvoju sportskog marketinga i sportskog menadžmenta odvijaju sa kašnjenjem od jedne decenije u odnosu na trendove u svetu. Iako je od sredine XX veka srpski sistem sporta beležio značajne takmičarske efekte, zbog finansiranja iz budžeta ekonomski aspekti su zanemareni. Opadanje performansi socijalističkih privreda je naročito je pogodilo sport, a posledice negativnih tendencija (starenje infrastrukture, demografski pokazatelji, mala izdvajanja države, socijalne nepravde, zloupotrebe u klubovima, neadekvatna zakonska i podzakonska akta, gašenje velikog broja klubova), su donekle ublažene preduzetničkom inicijativom i ulaganjem privatnog kapitala. Za to vreme druge zemlje beleže značajan rast sportskog tržišta (npr. samo od prodaje karata za sportske priredbe Real Madrid, ostvaruje veći priliv nego neke zemlje u razvoju od svog celokupnog godišnjeg izvoza).

Menadžment u sportu koresponira definiciji sporta (Evropska sportska povelja, 1992, čl. 2): Sport čine svi oblici fizičkih aktivnosti, koji putem povremenog ili organizovanog učestvovanja, teže unapređenju fizičke spremnosti i mentalne dobrobiti, formiranju društvenih odnosa ili postizanju rezultata u takmičenju svih nivoa. Istraživanja u oblasti menadžmenta u sportu u periodu od 1950-1980. godine, DAI (Dissertation Abstracts International, ProQuest) je bazirao na: poslovnoj politici, postupcima i primeni, analizi sadržaja nastavnih programa, odgovornosti i specifikacijama, ekonomskoj problematici, planiranju kapaciteta, finansijskim i budžetskim razmatranjima, liderstvu, pravnim i filozofskim aspektima, i organizacionim faktorima.

Sport ulazi u fazu varijeteta, nastajanje novih, parcelisanje postojećih sportskih grana i disciplina, stapanja nekih sportova, ili ukrštanja rekvizita. To znači da je ekonomija sporta podređena budućim zahtevima sporta, koji će veličinom i snagom sportske industrije uticati na ponašanje, stavove, motive i očekivanja sportista, i najšireg sportskog auditorijuma. Teorija sportskog menadžmenta u funkciji razvoja sporta i sportske industrije pravovremeno signalizira u kojem pravcu se kreće razvoj ostalih resursa sporta: infrastrukture, istraživanja i edukacije sportskih menadžera. Parcelizacija sportskog menadžmenta je refleksija segmenata sportske inudstrije koju prema Parksu et al. (1998) čine: univerzitetska takmičenja, profesionalni sport, poslovanje sportskim objektima, rekreativni programi u kampovima, sportovi na zajedničkoj osnovi, sportsko informisanje i novinarstvo, sportski menadžment, upravljanje sportskim klubovima, industrija za fizičku i fitnes rekreaciju, sportski trening i sportska medicina, obuka i vođenje sportova na vodi, konsalting, preduzetništvo i zastupanje u sportu. Značaj marketinga za menadžment u sportu je veliki; nagli razvoj sporta i sportske industrije zahteva da se on izdvoji kao posebna naučna disciplina. Naučna istraživanja u sportu su započeta iz dva smera: bivši sportisti su bogata iskustva prenosili dolazećim generacijama, uključujući se u formalne obrazovne procese kako bi usavršili kompetencije u skladu sa vremenskom linijom sportskog talenta kao retkog ljudskog resursa, čije performanse postepeno opadaju. To je stvorilo bogatu naučnu bazu u vidu teorije sporta. Sa druge strane, lica koja su pružala logističku podršku sportu, su znanja iz ekonomije i menadžmenta dopunjavala njome, pa se kao oslonci razvoja savremenog menadžmenta u sportu, smatraju upravo teorija sporta i ekonomija (marketing i menadžment).

\section{DISKUSIJA}

Sportski menadžment korene vuče iz Antičke Grčke (osnivanjem OI), oživljen je u periodu zadnja dva veka renesanse kroz organizovane aktivnosti, a preko engleskog establišmenta u savremenoj verziji praktikuje se ceo vek. Primena principa menadžmenta na sport daje pozitivne efekte (u okviru faza planiranje, organizovanje i vođenje), ali je nedovoljna, jer neki aspekti upravljanja sistemom sporta traže izdvojene pristupe. Za dalji razvoj sportskog menadžmenta bilo je presudno ustanovljenje posebne profesije, i poželjne koncentracije akademski obrazovanih ljudi koji su doprineli njegovoj afirmaciji. Kao samostalna profesija, sportski menadžment nastaje u Americi 1957. godine, kada su J. G. Mason, predavač fizičke kulture na Univerzitetu u Majamiju i W. O'Maley iz bejzbol kluba Bruklin Dodžers, ustanovili kurikulum menadžmenta u sportu. Kako su potrebe za kompetencijama, rastom sportske industrije uvećavane, SAD su postale zemlja sa najvećim brojem institucija u svetu koje obrazuju sportske menadžere (krajem XX veka bilo ih je preko 200, danas preko 500). Prvi univerzitetski program za menadžment u sportu osnovan je 1966. godine, u okviru master studija na Univerzitetu Ohajo. Od presudnog značaja za dalji razvoj menadžmenta u sportu bilo je obrazovanje eksperata na najvišem nivou studija - poslediplomske studije. Praksa da se 80 -ih godina XX veka, menadžment u sportu uvodi u neke srednje škole, kako bi univerziteti privukli nove studente, stvorila je široku bazu, te su u Americi osnovani: Udruženje za menadzment u sportu, umetnost i nauku (SMARTS - Sport Management Arts and Science Society), Udruženje sportskih menadžera Severne Amerike (NASSM - North American Society for Sport Management) i dr.

Od 1993. godine NASSM sprovodi standardizaciju kurikuluma, u okviru osnovnih, master i doktorskih studija. Razvoj profesije NASSM vrši kroz obrazovne ustanove i pojedince, i objavljuje listu univerziteta, koji obrazuju menadžere u sportu. Osim 470 univerziteta u SAD pod okriljem NASSM, COSMA (Comission on Sport Management Acreditation) akredituje još 42 institucije u SAD koje edukuju sportske menadžere do nivoa master studija. U Evropi je iste godine osnovana EASM (European Association for Sport Management). Njenih 26 članica obrazuju menadžere u sportu pod okriljem NASSM (od čega 9 u UK, a 5 u Španiji), osim 18 u Aziji, 17 u Kanadi, 13 u Australiji, 4 na Novom Zelandu, i po jednu u Indiji i Africi.

Razvoj sportskog menadžmenta u svetu i u Srbiji, pošao je od ocene stanja menadžmenta u sportu, nedostatka empirijskih argumenata, usvajanja postulata drugih disciplina, čime je stečen konceptualni okvir i pretpostavka za istraživanja. Radi provere paradigmi, analizirane su usvojene pretpostavke i konačno je izdvojena jedinstvena disciplina. Od institucionalizovanja kao posebne naučne oblasti, menadžment u sportu je ušao u fazu podele svojih i komplemantarnih područja sporta i sociologije, pod uticajem faktora kao što su: globalizam, suprotnost, fenomenologija, informatičke tehnologije, unifikacija 
i diverzifikacija stilova i kultura, estetika, sigurnost, i sl. Koncept na kojem se zasniva menadžment u sportu prema Parkhouse (2005) su studije sporta i poslovni menadžment. U Srbiji su razvijani pragmatični modeli primene principa menadžmenta na sport (Ljubojević, 2001; Kastratović, 2004; Dugalić, 2005; Tomić, 2007); da je sportski menadžment oblikovala ekonomija, iz koje su se izdvojili menadžment, marketing i finansije. Dalji uticaj na njegov razvoj imali su pravo i etika.

\subsection{SPORTSKI MENADŽMENT KAO FUNKCIJA, PROFESIJA I NAUKA U SRBIJI}

Prema Raiču (2006), profesija sportskih menadžera nastaje: formiranjem naučno-obrazovne infrastrukture institucija, sticanjem naučnog obrazovanja zaposlenih u sportu kao sferi delatnosti sa potvrđenom društvenom funkcijom, i organizovanjem njenih pripadnika u instituciju koja kontroliše tržište rada u domenu za koji je ta profesija zainteresovana. Studije menadžmenta u sportu u Srbiji započinju osnivanjem Više trenerske škole u Beogradu 2000. godine, kao dvogodišnje studije (sa 13 predmeta) koje su prerasle u trogodišnje (sa 20 predmeta), i akreditovane kao prve strukovne studije menadžmenta u sportu (sa 26 predmeta). Zalaganjem autora rada studije su zatim akreditovane kao osnovne i master akademske studije u okviru Fakulteta za fizičku kulturu i menadžment u sportu. U međuvremenu je Fakultet za menadžment u sportu osmislio svoj akademski program koji je uključivao diplomske, magistarske i doktorske studije.

U Srbiji je na bazi Zakona o sportu donet Pravilnik o nomenklaturi sportskih zanimanja i zvanja (1999. i 2013. godine). Prema članu 39 tog pravilnika oblasti rada menadžera u sportu su:

- organizovanje utakmica, susreta i takmičenja;

- organizovanje sistema takmičenja i učestvovanje u realizaciji sistema takmičenja;

- planiranje korišćenja objekata i kontrola njegovog izvršenja;

- pripremanje programa i projekata u oblasti sporta i kontrola njihovog izvršenja;

- pripremanje sastanaka stručnih organa i organa upravljanja;

- nadzor nad internom dokumentacijom;

- interno informisanje članova o radu organizacije u oblasti sporta i informisanje trećih zainteresovanih lica;

- marketinške aktivnosti, propagandne aktivnosti;

- saradnja unutar i između organizacija u oblasti sporta u zemlji i inostranstvu;

- vođenje poslovanja;

- sklapanje ugovora;

- sprovođenje odluka upravnih i stručnih organa organizacije u oblasti sporta.

Sporno je to što se pored ovog zvanja, u pravilniku navode i zvanja koja se preklapaju: organizator rekreacije u sportu, organizator sportskog poslovanja, sportski posrednik, sportski dokumentalista, novinar u sportu, sportski propagandista i savetnik u sportu. Najviše zvanje koje se ovim pravilnikom može steći je menadžer specijalista. Doktorske studije nisu pomenute pravilnikom, iako se u Srbiji obrazuju doktori menadžmenta u sportu duže od deset godina. Pravilnik o stručnom osposobljavanju za sportsko zanimanje menadžer u sportu i druga zvanja, nudi stručno osposobljavanje (kurs). To je čak oblik naučnoistraživačkog rada i saradnje obrazovnih institucija prema Strategiji razvoja sporta za period 2014-2018. godine. držaji:

Ovaj program stručnog osposobljavanja čine nastavni sa-

1. menadžment u sportu;

2. marketing u sportu;

3. osnovi sportske organizacije;

4. ekonomika sporta i finansiranje sporta;

5. zaštita zdravlja i antidoping u sportu;

6. upravljanje sportskim projektima;

7. upravljanje sportskim objektima;

8. upravljanje sportskim priredbama;

9. sportsko pravo;

10. upravljanje bezbednosnim i drugim rizicima u sportu;

11. osnove sportske statistike i informatike.

Profesiji sportskog menadžera problem stvara i neobjavljena lista akademskih i naučnih naziva, koja je pored postojeće razuđene strukture kurikuluma i naziva profesija, postala prepreka standardizaciji i sistemu akumulacije, kojem se teži.

U Srbiji je 2004. godine osnovana ASMS (Asocijacija sportskih menadžera). Strukovno organizovanje se čini bespotrebno, ako država favorizuje kurseve. U Izveštaju po osnovu programa javne rasprave o predlogu nacionalne strategije za razvoj sporta za period 2014-2018. godine, naglašen je problem nesprovođenja pravnih akata u sportu: učinjen je osvrt na Pravilnik o stručnom osposobljavanju za sportsko zanimanje menadžer u sportu i druga zvanja, licenciranje, nomenklaturu (str. 5); i problem univerzitetskog sporta - nedostatak novca, infrastrukture, osnivanje lige i sl. (str. 7).

Ovi zaključci nisu uneti u strategiju: Visokoškolske ustanove za sport i menadžment u sportu, kao činioci sistema sporta imaju veoma važnu ulogu u smislu razvoja i unapređenja sporta i potrebno je raditi na postizanju bolje saradnje između sportskih organizacija i naučnih institucija (Strategija razvoja sporta u Republici Srbiji za period 2014-2018. godine, str. 12). U Akcionom planu za sporovođenje ove strategije u odeljku Stručno i naučno-istraživački rad u sportu i informacionim sistemima, pododeljku i posebnom cilju: Podizanje kapaciteta Zavoda za sport i medicinu sporta Republike Srbije i pokrajinskih zavoda za sport i medicinu sporta, predviđa se povezivanje sa visokoškolskim ustanovama, bez preciziranja vrste povezivanja (osim organizovanja kurseva), a akcenat u odeljku koji uređuje naučno-istraživački rad u sportu, sveden je na izradu sajta. Projekti Ministarstva omladine i sporta svedeni su na Odluku o dodeli Ugovora za rekonstrukciju i adaptaciju malih sportskih terena. Posle jednog veka primene menadžmenta u sportu u svetu, nadležno ministarstvo i državne obrazovne ustanove u Srbiji, iz oblasti sporta i fizičke kulture, ne prepoznaju njegov značaj (nije uvršten u kurikulum, ni opciono). Privatne obrazovne ustanove sportske menadžere edukuju od početka XXI veka, čime doprinose razvoju sporta, nauke, privrede i društva u celini.

\subsection{DIVERZIFIKACIJA MENADŽMENTA U SPORTU}

Prema Pitsu i Stotlaru (1996), specijalistička područja u sportu su: studije sporta, vođenje poslova, komunikacije i društvene nauke. U okviru studija sporta izučavaju se: filozofija sporta, psihologija sporta, sociologija sporta, vođenje fizičkog vaspitanja, profesionalnog sporta, rekreacije, i priprema učesnika.

Vođenje poslova uključuje: marketing, finansijski menadžment, ekonomiju, poslovno pravo, ponašanje potrošača, menadžment ljudskih resursa i menadžment. Komunikacije uključuju: novinarstvo, odnose s javnošću, proučavanje medija, oglašavanje, i emitovanje. U društvene nauke kategorizovali su: ljudske odnose, proučavanje multikulture, proučavanje stanovništva i 
proučavanje tržišta rada. U tom teorijskom pristupu se uočava da su filozofiji sporta, psihologiji sporta i sociologiji sporta već pridruženi širi značaji (kao posebnom kontekstu društvenih nauka). Kada se posmatra vođenje poslova, marketing se izdvaja iz ekonomije, a ponašanje potrošača iz marketinga, a finansijski menadžment kao i menadžment ljudskih resursa iz opšteg (poslovnog) menadžmenta. Posmatrajući komunikacije, opaža se da su odnosi s javnošću, mediji i oglašavanje izdvojeni iz marketinga.

Diskusije o specijalističkim područjima sporta, ukazuju da su možda neka rešenja potvrđena u praksi, ali kada se analiziraju teorijski aspekti, uočavaju se nekompatibilnosti. Pokušaj imeplementacije poslovnog prava na sport, kroz sportsko pravo, dovodi do toga da se napušta praksa izučavanja obligacionog i stvarnog prava, što je pogrešno iz više razloga: njegova primena u sportu se više orijentiše na klubove (institucije sporta), a udaljava od obrasca kompetencija menadžera neophodnih za industriju sporta (sportske delatnosti), koja podržava sport. Možda najveće nedoumice u navedenom pregledu studija sporta potiču od komunikacija. Ukoliko sportski menadžeri svoju vokaciju zasnivaju na prethodnom znanju stečenom u okviru ekonomskih nauka, naići će na problem loše vođene sportske prakse. Ako se odnosi s javnošću kao i sponzorstvo, posmatraju izvan konteksta promotivnog miksa, a ne obrnuto, zbog poistovećivanja promocije sa komunikacijom, predozirana komunikacija (koje potiče iz potrebe sportskog informisanja), opterećena troškovima, na tržištu se ne valorizuju (npr. kada udeo prodatih ulaznica čini jedva $10 \%$ od ukupnog prihoda). Proizvedena a neželjena, skupa komunikacija (tržišno neatraktivna) opterećuje sportske proizvode, koji se usled visoke konkurentnosti ne mogu realizovati na sportskom tržištu.

Slični problemi se javljaju kada se marketing posmatra izolovano od njegove glavne funkcije: pružanje satisfakcije korisnicima u cilju rasta prodaje. Ukoliko marketing ne doprinosi valorizaciji sportskog proizoda po vrednosti iznad cene koštanja (koja pokriva marketinški budžet), komunikacija, odnosi s javnošću i sl. aktivnosti postaju bezpredmetne. Tako ovaj koncept primene komunikacija nije poželjan za sportsku industriju, a praksa pokazuje da ako se izuzme sportsko izdavaštvo, nije pragmatičan ni za sistem sporta (sportske organizacije, sportske manifestacije). Parcelizacija sportskog brenda izvan marketinga, gde je izvorno nastao je takođe izvor problema sportske prakse. Ako se npr. sportski rezultat, sportski imidž, i sportska marka objašnavaju nezavisno od sportskog doživljaja i događaja, stvara se diskontinuitet u lancu vrednosti sportskog proizvoda. Osamostaljivanje rezultata, imidža i brenda treba da je zasnovano na prethodno realno kalkulisanom učešću i obeštećenju sportistima za uložene i afirmisane performanse. Kako se u lancu interesnih učesnika javljaju nezavisni pravni subjekti koji imaju drugačije misije i ciljeve od sistema sporta i sportske industrije (država, mediji, marketinške agencije, konsultantske grupe), stvara se piramidalni efekat koji devastira sport jer je on primarno zasnovan na isporuci satisfakcije publici. Ona se usled široke game industrije zabave i sl. faktora (starenje ciljne grupe, menjanje potrošačkih navika, izmene u kupovnoj moći, itd.) postepeno raslojava, te ne može da apsorbuje očekivane, obogaćene ili potencijalne sportske proizvode (rezultat, imidž, brend).

Sportski proizvodi mogu biti opipljivi i neopipljivi (materijalni ili nematerijalni, konzistentni ili oni koji nemaju supstancu). U praksi se pogrešno poistovećuju sportski proizvod i usluga (ili se među njima ne prave razlike koje se odnose na: poimanje elementa biti, srži, i jezgra funkcionalne korisnosti sportskog proizvoda, izraza očekivanja publike u vidu sportskog rezultata) sa samim sportskim događajem; govori se o imidžu sportskog brenda (imidž je niži po hijerarhiji u lancu vredno- sti za potrošače od brenda, Dugalić, 2008), i sl. Ovo zato jer je zanemaren značaj korisnosti neopipljivog proizvoda (ili je zamagljen), a emotivnost kao njegova druga značajna odlika se posmatra iracionalno (iako se prag apstinencije ili tolerancije korisnika (publike) može precizno kvantifikovati). Važna karakteristika sportskog događaja, kao osnovnog proizvoda (strukturiranog u 5 nivoa prema Kotleru), je da se nikada ne isporučuje samostalno, već zajedno sa ostalim sportskim proizvodima. To mogu biti opipljivi sportski proizvodi (npr. rekviziti, suveniri), sportske usluge, drugi neopipljivi sportski proizvodi, ili proizvodi i usluge koji sa sportom nemaju nikakve sličnosti ali su njima komplementarni (hrana, piće, usluge parkinga), čineći jedinstveni i neponovljivi sportski asortiman.

Marketingmanija u sportu stvara osamostaljena područja komunikologije. On postaje predoziran po broju predmeta i zastupljenosti u okviru kurikuluma i fonda časova, dok praktične veštine opravdavaju učešće ukoliko to ankete diplomiranih studenata dokažu. U tim analizama se vrednuje zadovljstvo poslodavaca stečenim veštinama zaposlenih sportskih menadžera, u postupku samoevaluacije, putem mernih procedura. Tomić (2007), objašnjava kako profitni koncept sporta jača na teret njegove neprofitne komponente težeći da je ukine, zbog čega ne treba u sportskoj praksi umanjiti značaj ekonomije i finansija. Teorija sportskog menadžmenta objašnjava da je sport bez ekonomske logike neodrživ, a da sistem sporta ima institucionalno ugrađene mehanizme odbrane od samouništenja (nemogućnost promene namene sportskih objekata, razdvajanje sporta na profitni i neprofitni koncept, obaveza reinvestiranja i oporezivanja, zakonska regulativa i sl.). Konkurentnost je neodvojiva od sporta, zapravo ona ga je stvorila, te će u budućnosti sport sam proizvesti obrambene mehanizme, kako bi se prilagođavao privrednim i društvenim promenana.

Od sredine prošlog veka marketing i menadžment se izučavaju i nezavisno od ekonomije, kao što je to slučaj u drugim privrednim granama. Parcelizacija menadžmenta (pored potrebe da se izučava kao opšti ili poslovni menadžment), stvara dve ključne oblasti koje korespondiraju sa najznačajnijim resursom sporta: menadžment ljudskih resursa i finansijski menadžment. Ovaj pristup zanemaruje ostale resurse sporta kao što je sportska infrastruktura (sportski objekti) jer njihova izgradnja i ekspolatacija postaju veoma kompleksni. Sa druge strane, menadžment ljudskih resursa se primarno bavi zaposlenima u sistemu sporta, a malo ili nimalo samim sportistima (sportskim talentom). U selekciji sportista potrebno je uvažiti značaj menadžmenta ljudskih resursa, i obratno, menadžeri moraju imati specijalistička znanja za prepoznavanje i vođenje mladih talentovanih sportista u njihovoj karijeri. Takođe, uočava se umanjen značaj naučnih istraživanja i menadžmenta zdravlja $\mathrm{u}$ domaćim nastavnim planovima za edukaciju menadžera $\mathrm{u}$ sportu, što ostavlja izvesni vakum.

\subsection{PERSPEKTIVE I SMERNICE RAZVOJA MENADŽMENTA U SPORTU}

Mulin (2007), menadžment u sportu tumači kao proces planiranja, organizovanja, vođenja i ocenjivanja delatnosti u okviru organizacije čiji je osnovni cilj omogućavanje realizovanja sportskih ili rekreativnih aktivnosti, proizvoda i/ili usluga. Ovaj pristup korespondira sa Parkhouse (2005). Prema Kastratović (2004), multidisciplinaran pristup je usklađena tvorevina prožeta saradnjom više disciplina, pre svega poslovnog menadžmenta i obrazovanja u oblasti fizičke kulture. Ovde se teži nadogradnji znanja iz menadžmenta, specijalističkim znanjima iz fizičke kulture. 
Sportski menadžment je proces u okviru kojeg se sinhronizuju aktivnosti:

1. upravljanje sportskim resursima, sportskim procesima i sportskim sistemom;

2. rukovođenje sportskim aktivnostima u celini ili parcijalno;

3. planiranje sportskih aktivnosti svih grana, vrsta i nivoa, tj. poslovanja u sportu;

4. donošenje sportskih odluka i usmeravanje procesa odlučivanja;

5. razvijanje i kontrola marketing aktivnosti;

6. kontrola nad sportskim informacijama i komunikacijama;

7. sportski kontakti i sportski odnosi prema sportskim subjektima;

8. negovanje preduzetničke filozofije i stalne edukacije.

U zavisnosti od okruženja menadžmenta u sportu, moguće ih je realizovati u segmentu:

1. sporta za potrebe rekreacije i razonode (školski i univerzitetski sport, organizacije koje nude sportske i fitnes programe, privatni ili društveni sportski klubovi);

2. sportsko i takmičarsko okruženje (školska i univerzitetska takmičenja, profesionalni sport, poslovi menadžmenta u sportu);

3. proizvodnja i plasman sportske opreme (sportski marketing, prodaja);

4. poslovi vezani za smeštaj, programe za rekreaciju i razonode i adekvatnu infrastrukturu (sportski objekti, sportski turizam, tematski parkovi, aktivni godišnji odmori, hoteli, putovanja),

5. poslovi zastupanja u sportu (neprofitne, vladine i nevladine organizacije, udruženja i sl.).

Sport se još segmentira na: profesionalni sport, rekreativni i sport za posebne grupe korisnika. Moguća je podela sporta na: sport visoke performanse, konkurentski sport, i tzv. sport za sve. Ovi pristupi određuju osnovu na kojoj menadžment u sportu egzistira i čije zahteve, očekivanja i misije treba da ispuni.

Organizator sportskih manifestacija međunarodnog karaktera mora biti osposobljen za:

1. planiranje, konstruisanje, izgradnju, održavanje i upravljanje objektima za održavanje prvenstva;

2. prateću oprema za funkcionisanje prvenstva,

3. informaciono-komunikacione objekte i opremu;

4. hospitalizaciju sudionika;

5. transportne usluge;

6. nabavku optimalnih količina prateće opreme i rekvizita;

7. inventarisanje postojeće i nove opreme i objekata;

8. brigu o bezbednosti učesnika;

9. budžetiranje, određivanje uslova prodaje i troškova (inventara, transporta, nabavke, skladištenja, informaciono-komunikacionih) putem standardizovane usluge koju mora ispuniti da ne dođe do pomeranja rokova i dodatnih troškova (Dugalić, 2007).

Organizacija se zato odvija pod pokroviteljstvom vlada kao garanta uspešnosti (npr. SAD, Japana, Nemačke) čime one participiraju u podeli sportskog imidža i brenda. Zbog velikog broja učesnika, kratkoće trajanja manifestacije, neizvesnosti ishoda i sl., upravljanje projektima u sportu dobija na značaju. Cena usluga uključuje sve vrste troškova i zahteve u pogledu: brzine, sigurnosti, udobnosti, tačnosti i masovnosti. Informaciono-komunikacioni troškovi primenom adekvatne tehnologije povećavaju konkurentnost, smanjuju cene usluga, otklanjaju frustracije i utiču na povećanje profita. Za projektovanje i praćenje tokova sredstava koriste se savremeni softveri, a vrednovanje se provodi sa aspekta krajnjih korisnika (tržišni kriterijum). Visok nivo usluga treba obezbediti uz što niže prosečne troškove, jer sportskim proizvodima i uslugama konkuriše velik broj supstituta (asortiman zabave i dokolice). Primena informacione tehnologije i projektnog sistema smanjuje vreme potrebno za organizovanje događaja, doprinosi maksimalizaciji profita i uvećava konkurentnost. Organizovanje događaja je nemoguće bez sertifikata za ispunjavanje brojnih kriterijuma i referenci i njime treba upravljati (Dugalić, 2005).

Osim nedovoljno istraživačkog rada u sportu, poređenjem sa trendovima u svetu, u Srbiji je umanjen značaj finansija (iako je to goruće pitanje opstanka srpskog sporta), koje se uglavnom izučavaju u okviru jednog opcionog ili obaveznog predmeta: Poslovnih finansija, Finansijskog menadžmenta; ili sa Ekonomijom sporta. Ekonomija sporta je malo zastupljeno područje izučavanja. Treba imati u vidu da je mali broj studenata koji se opredeljuju za menadžment u sportu posle završene srednje ekonomske škole, bez prethodnog znanja iz ekonomije. Ekonomija sporta treba da izučava problem prestrukturiranja: privrede (ulogu države i odnos prema sportu), grane (tehnologije sportsko-uslužnih procesa) i sportskih organizacija (poslovno i vlasničko restrukturiranje, nove organizacione forme, razgraničenje imovine). Prestrukturiranje je važno zbog: prilagođavanja tržišnom poslovanju, investicionih potreba i ograničenja u pogledu imovine i nemogućnosti promene namene, zaposlenosti i interne organizacije (uključivanje sadašnjih i bivših sportista u sistem sporta prethodno edukovanih na teret budžeta, negovanje korporativne kulture, promena pravnog statusa i sl.(Dugalić, 2006).

\section{ZAKLJUČAK}

Istražujući nastanak, razvoj i konstituisanje menadžmenta u sportu, može se zaključiti da je u sportskoj praksi prisutna velika razuđenost njegove primene, što se odražava na širinu i obuhvat specijalističkih područja. Misija obrazovanja je da zadovolji potrebe sportskog tržišta, za specifičnim profilima, ali se dešava 'preslikavanje' rešenja i programa zemalja koje imaju već razvijeno sportsko tržište (SAD, Engleska). Usklađivanje programa sa evropskim obrazovnim prostorom kojem Srbija teži, ostavlja vakum vezan za specifične forme i procese restrukturiranja sistema sporta, imovinu, konkurentnost zemlje, grane i sektora, institucionalna rešenja sistema sporta i sl. Potencijal sporta (demografska struktura, razvijenost tržišta, visina društvenog bruto proizvoda, nacionali dohodak po glavi stanovnika, globalni indeks konkurentnosti, itd.) Srbije odražava specifičan sistema sporta, zbog kojeg treba ispitati, a dopunjavati iskustva razvijenih zemalja karakteristikama kao što su: tradicija, nasleđe socijalističkih privrednih formi, struktura i tendencija razvoja sporta, i realan okvir (nacionalna strategija razvoja sporta, analiza izvodljivosti), za ostvarenje misije i vizije srpskog sporta.

Glavni oslonci konkurentnosti nacionalnog sporta su:

1. obuka i obrazovanje,

2. infrastruktura (institucije, sistem sporta, mreža sportskih objekata i sl.) i

3. istraživanja koja bi odredila dalji pravac aktivnosti i realizaciju vizija svih sektora sporta, učesnika i države.

U svetu, zavisno od pozicije sporta u privrednom sistemu zemlje, najveći značaj u edukaciji daje se marketingu, menadžmentu u sportu, njegovim specijalističkim područjima i primenjenim istraživanjima na privatnim univerzitetima. Državne obrazovne ustanove sa većim naučno-istraživačkim kapacitetom treba da teže fundamentalnim istraživanjima menadžmenta u 
sportu. Međutim, u Srbiji menadžment u sportu na državnim fakultetima nije zastupljen ni kao izborni predmet.

Optimalan odnos sa akterima sportskog sistema država mora uspostaviti balansom u strukturi i dinamici poslovanja, sa finansijskog, marketinškog, ekonomskog, sociološkog i političkog aspekta. S obzirom na karakter sportskog subjekta u praksi treba sinhronizovati aktivnosti: menadžmenta sistema sporta; menadžmenta sportskog subjekta; sportskog menadžmenta adekvatne sportske zajednice; i menadžmenta određenih sportskih delatnosti, sistema ili sportskih struktura. Zbog globalnog karaktera sporta i visoke uključenosti u globalnu konkurenciju, sociologija, izučavanje multikulturnih razlika i standardizacija će dobijati na značaju. Vrednovanje programa mora uvažiti te pristupe, a obrazovne institucije i sportski menadžeri odgovoriti zahtevima, izboriti se da se u uređenju sistema sporta više uvažavaju njihova znanja, stavovi i preporuke.

\section{LITERATURA}

Dugalić, S. (2005). Finansijski i marketinški aspekti strategija u sportu. Beograd: Visoka škola za sport.

Dugalić, S. (2006). Teorijski aspekti i praktični problemi restrukturiranja savremenog sporta. Nova sportska praksa. 1(2), 49-61.

Dugalić, S. (2007). Menadžment sportskih objekata. Beograd: Visoka sportska i zdravstvena škola.

Dugalić, S. (2008). Definisanje i konceptiranje sportskog proizvoda. Nova sportska praksa. 3(2), 56-71.

Sportski savez Srbije. (2012). Evropska sportska povelja. Preuzeto 14.3.2015. sa www.serbiansport.com/pravna-akta/ savet-evrope/

Kastratović, E. (2004). Osnove menadžmenta sa menadžmentom u sportu. Beograd: Institut za razvoj malih i srednjih preduzeća.
Ljubojević, Č. (2001). Menadžment i marketing u sportu. Beograd: Želnid.

Mullin, B.J., Hardy, S., Sutton W.A. (2007). Sport Marketing. Champaign, IL: Human Kinetics Publishers.

NASSM. (2015). Sport Management Programs: United States. Preuzeto 8.3.2015. sa www.nassm.com/InfoAbout/SportMgmtPrograms/United_States/

Parkhouse, B. L. (2005). The Management of Sport: Its Foundation and Application. NY: McGrawHill.

Parks, J.B, Zanger, B.K., \& Quarterman, J. (1998). Contemporary Sport Management. Champaign, IL: Human Kinetics Publishers.

Pitts, B., \& Stotlar, D. (1996). Fundamentals of Sport Marketing. Morgantown: FIT Inc.

ProQuest. (2015). Dissertation Abstracts International. Preuzeto 07.03.2015 sa http://www.proquest.com/products-services/dissertations/Dissertations-Abstract-International. html.

Službeni glasnik RS. (2011). Zakon o sportu. Službeni glasnik RS br. 24/11 i 99/11 - dr. zakon.

Službeni glasnik RS. (2013). Pravilnik o nomenklaturi sportskih zanimanja i zvanja, Sl.glasnik RS br. 7/2013.

Službeni glasnik RS. (2013). Pravilnik o stručnom osposobljavanju za obavljanje određenih stručnih poslova u sportu. Službeni glasnik RS, br. 8/2013.

Raič, A. (2006). Sportski menadžment kao profesija i kao nauka. $2^{\text {nd }}$ International conference Management in sport. Beograd: Fakultet za menadžment u sportu, Univerzitet Braća Karić.

Tomić, M. (2007). Sportski menadžment. Beograd: Data status. 